\title{
Article \\ Implementing Public Health Strategies-The Need for Educational Initiatives: A Systematic Review
}

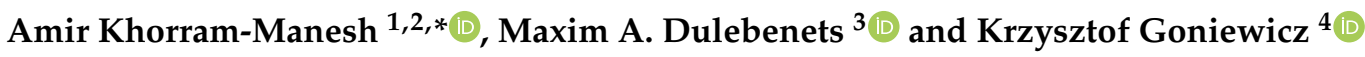 \\ 1 Department of Surgery, Institute of Clinical Sciences, Sahlgrenska Academy, Gothenburg University, \\ 41345 Gothenburg, Sweden \\ 2 Department of Development and Research, Armed Forces Center for Defense Medicine, Gothenburg, \\ 42676 Västra Frölunda, Sweden \\ 3 Department of Civil \& Environmental Engineering, College of Engineering, Florida A\&M University-Florida \\ State University (FAMU-FSU), 2525 Pottsdamer Street, Building A, Suite A124, \\ Tallahassee, FL 32310-6046, USA; mdulebenets@eng.famu.fsu.edu \\ 4 Department of Aviation Security, Military University of Aviation, 08521 Deblin, Poland; \\ k.goniewicz@law.mil.pl \\ * Correspondence: amir.khorram-manesh@surgery.gu.se
}

Citation: Khorram-Manesh, A.; Dulebenets, M.A.; Goniewicz, K. Implementing Public Health

Strategies-The Need for Educational Initiatives: A Systematic Review. Int. J. Environ. Res. Public Health 2021, 18, 5888. https://doi.org/10.3390/ ijerph18115888

Academic Editors: Peng Bi and Paul B. Tchounwou

Received: 26 April 2021

Accepted: 28 May 2021

Published: 30 May 2021

Publisher's Note: MDPI stays neutral with regard to jurisdictional claims in published maps and institutional affiliations.

Copyright: (c) 2021 by the authors. Licensee MDPI, Basel, Switzerland. This article is an open access article distributed under the terms and conditions of the Creative Commons Attribution (CC BY) license (https:// creativecommons.org/licenses/by/ $4.0 /)$.

\begin{abstract}
In the absence of a specific treatment or vaccines, public health strategies are the main measures to use in the initial stages of a pandemic to allow surveillance of infectious diseases. During the ongoing global pandemic of coronavirus disease 2019 (COVID-19), several countries initiated various public health strategies, such as contact tracing and quarantine. The present study aims to conduct a systematic literature review to identify the presence of educational initiatives that promote the implementation of public health strategies before public health emergencies, with a special focus on contact tracing applications. Using Science Direct, PubMed, Scopus, and Gothenburg University search engines, all published scientific articles were included, while conference, reports, and non-scientific papers were excluded. The outcomes of the reviewed studies indicate that the effective implementation of public health strategies depends on the peoples' willingness to participate and collaborate with local authorities. Several factors may influence such willingness, of which ethical, psychological, and practical factors seem to be the most important and frequently discussed. Moreover, individual willingness and readiness of a community may also vary based on the acquired level of knowledge about the incident and its cause and available management options. Educational initiatives, proper communication, and timely information at the community level were found to be the necessary steps to counteract misinformation and to promote a successful implementation of public health strategies and attenuate the effects of a pandemic. The systematic review conducted as a part of this study would benefit the relevant stakeholders and policy makers and assist with effective designing and implementation.
\end{abstract}

Keywords: contact tracing; ethics; pandemic; psychology; public education; public health

\section{Introduction}

The unpredictable development of the coronavirus disease 2019 (COVID-19) resulted in a global pandemic beginning in 2020, spreading from one region to another [1]. Consequently, countries had to rely on traditional public health measures such as isolation, containment, quarantine, and contact tracing strategies [2-6]. However, these urgently implemented measures had varying success in halting the spread of the disease globally, either due to shortcomings in countries' infrastructure or their financial capabilities. New waves of viral infection started spreading again as soon as society opened up $[3,6]$.

In response to the worsening situation, several countries started various means of contact tracing and isolation of their citizens [7-12]. Contact tracing represents one strategy, which slows down the spread of the viral infection and enables the identification of infected 
cases or those at risk, either by listing all people with whom an infected person has recently been in contact, or by using location-tracking mobile applications (apps) [7-11,13-16]. There has been an intensive development of contact tracing applications (CTA), using various means of technology, including QR (Quick Response) codes; GPS (Global Positioning System); credit card transmission log; CCTV (Closed Circuit Television); different COVID alert apps; and Bluetooth [1,10-20]. However, the inadequate level of public compliance with these public health strategies has resulted in mandatory contact tracing strategies as part of a government strategy in some countries $[8,17,21]$. Within the European Union (EU), in some nations, authorities together with telecommunications providers started sharing people's anonymous location data on map concentrations, respecting the Europe's privacy laws and individuals' rights to privacy [8,9,21-27].

Although the use of these apps seems necessary and beneficial, they seem to create several challenges, such as ethical, psychological, and practical, that may influence the willingness of individuals and a community to implement these measures actively $[22,23,25]$. The willingness itself is proven to be dependent on the level of information and knowledge, especially when dealing with unknown threats [28]. Adequate knowledge about incidents, their etiology, and the available management options enables recognition of the threats and acceptance of necessary strategies during public health emergencies. Consequently, community preparedness and mental readiness seem to be some of the most important elements in successful policy implementation [20,29-44]. It is therefore evident that investing in local empowerment by establishing educational initiatives, proper communication, and timely information are all necessary steps to counteract misinformation and to promote successful implementation of public health strategies, which will further attenuate the pandemic.

The present study aims to conduct a systematic literature review to identify the presence of educational initiatives that promote the implementation of public health strategies before public health emergencies, with a special focus on contact tracing applications. It also aims at opening discussions and creating a basis for the exchange of information from the countries implementing similar solutions, especially European countries, with which joint actions could be undertaken.

\section{Materials and Methods}

This review was conducted in accordance with the Preferred Reporting Items for Systematic Reviews and Meta-Analyses (PRISMA) guidelines and its flow diagram [45]. The searching process included articles and the PRISMA checklist for each considered study and abstract were completed and attached to this manuscript (Appendices A-C). The scientific evidence of each selected article was assessed, by using the Health Evidence Quality Assessment Tool (Appendix D), as Strong, Medium, and Weak [46]. Initially, Google Scholar was used as the testbed to estimate the number of hits and adjust the searching keywords accordingly. In the next step, Science Direct, Scopus, PubMed, and Gothenburg University's Super search engines were used for a systematic search. The inclusions criteria were original research studies published in English. The exclusion criteria were conference papers, abstracts, reports, and non-scientific publications.

The research group performed the initial screening of all abstracts and titles independently to determine whether to include or exclude an article based on pre-defined selection criteria. The content analysis method was used to assess the eligibility of included papers, focusing on similarities and differences in the findings to present the tentative results [47]. During the abstract and title screening phase, a level of agreement on inclusion and exclusion was achieved among the authors. The third author reconciled disagreements (if any) between the first two authors to achieve a mutual consensus before moving to the full-text review. The full-text articles were assessed for inclusion, and the reasons were documented for all the excluded papers. The outcome was grouped based on the content analysis into four topics: practical, ethical, psychological, and educational aspects of public 
health emergency measures. Appendix A shows the combination of used search keywords and Table 1 illustrates the information about included studies. The key terms are as follows:

- Public Health Strategies

- Public Health Emergency

- Contact Tracing

- Isolation

- Quarantine

- Public Education

A standard data extraction form was used to collect the authors, article title, year published, journal title, study design, brief description of methods, primary outcome measures, and conclusions by all the authors for the articles included for full-text inclusions in the last step. References of the papers initially found were not included for evaluation. The search results from each database were exported to Microsoft Excel, merged, and sorted for removal of duplicate citations. Each article's reference list was checked to identify reliable and relevant articles for inclusion into the final review list. 


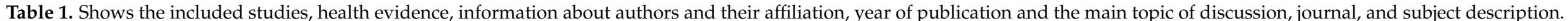
Topics are shown as E = Ethical, Ed = Educational, $\mathrm{P}=$ Practical, and Ps = Psychological

\begin{tabular}{|c|c|c|c|c|c|c|c|}
\hline No. & Health Evidence & Author(s) & Year & Topic & Country & Journal & Subject \\
\hline 1 & M & Nelson et al. & 2007 & $\mathrm{P}$ & USA & Am J Public Health & $\begin{array}{c}\text { Conceptualizing and defining public health emergency } \\
\text { preparedness }\end{array}$ \\
\hline 2 & M & Charania et al. & 2011 & Ed, $P$ & Canada & Int J Circumpolar Health & $\begin{array}{l}\text { The } 2009 \text { H1N1 pandemic response in remote First Nation } \\
\text { communities of Subarctic Ontario: barriers and improvements } \\
\text { from a health care services perspective }\end{array}$ \\
\hline 3 & S & Charania et al. & 2012 & Ed, $P$ & Canada & BMC Public Health & $\begin{array}{l}\text { A community-based participatory approach and engagement } \\
\text { process create culturally appropriate and community informed } \\
\text { pandemic plans after the 2009 H1N1 influenza pandemic }\end{array}$ \\
\hline 5 & S & Cantey et al. & 2013 & Ed, $P$ & USA & J Public Health Manag Pract & $\begin{array}{c}\text { Public health emergency preparedness: lessons learned about } \\
\text { monitoring of interventions from the National Association of } \\
\text { County and City Health Official's survey of nonpharmaceutical } \\
\text { interventions for pandemic H1N1 }\end{array}$ \\
\hline 6 & $\mathrm{M}$ & Rothstein & 2015 & E, P & USA & SSRN. Ind Health Law Rev & Legal and ethical considerations for modern quarantine \\
\hline 7 & M & Bachtiger et al. & 2020 & P, Ps & UK & medRxiv & $\begin{array}{l}\text { Government policy and reduced willingness to participate in } \\
\text { app-based contact tracing }\end{array}$ \\
\hline 8 & S & Joo et al. & 2020 & Ed, P, Ps & S. Korea & Service Business & $\begin{array}{l}\text { Resolving the tension between full utilization of contact tracing } \\
\text { app services and user stress as an effort to control the } \\
\text { COVID-19 pandemic }\end{array}$ \\
\hline 9 & M & Khorram-Manesh et al. & 2020 & E, P, Ed & Sweden & Disaster Med Public Health Prep & $\begin{array}{l}\text { Association between welfare, developed infrastructure and } \\
\text { prosperity of a country with infectious disease spread }\end{array}$ \\
\hline 10 & M & Alanezi et al. & 2020 & P, Ed & Saudi Arabia & J Healthcare Leadership & $\begin{array}{l}\text { A comparative study on the strategies adopted by several } \\
\text { countries to contain the spread of the COVID-19 pandemic }\end{array}$ \\
\hline 11 & M & Nazareth et al. & 2020 & P, Ed & UK & Lancet & Early lessons from a second COVID-19 lockdown in Leicester, UK \\
\hline 12 & M & Abeler et al. & 2020 & $\mathrm{P}, \mathrm{E}$ & UK & JMIR mHealth uHealth & COVID-19 contact tracing and data protection \\
\hline 13 & M & Hernandez-Quevedo et al. & 2020 & $\mathrm{P}, \mathrm{E}$ & European Union & The Health System Response Monitor & $\begin{array}{l}\text { How do countries structure contact tracing operations and what } \\
\text { is the role of apps? }\end{array}$ \\
\hline 14 & M & Du et al. & 2020 & $\mathrm{P}, \mathrm{E}$ & China & $J M I R$ & $\begin{array}{l}\text { COVID-19 contact tracing apps and gaps for international } \\
\text { pandemic control }\end{array}$ \\
\hline 15 & S & Korea CDC & 2020 & $\mathrm{P}$ & S. Korea & Osong Public Health Res & $\begin{array}{l}\text { Contact transmission of COVID-19 in South Korea and novel } \\
\text { investigation techniques for tracing contacts }\end{array}$ \\
\hline 16 & M & Rowe et al. & 2020 & E, P & France & Eur J Info Sys & Contact-tracing apps and alienation in the age of COVID-19 \\
\hline
\end{tabular}


Table 1. Cont.

\begin{tabular}{|c|c|c|c|c|c|c|c|}
\hline No. & Health Evidence & Author(s) & Year & Topic & Country & Journal & Subject \\
\hline 17 & $\mathrm{~S}$ & McGrail et al. & 2020 & E, P, Ps & Canada & AJPH & Contact-tracing apps and broader societal change \\
\hline 18 & S & Bernard et al. & 2020 & E, Ps & UK & $A J P H$ & $\begin{array}{l}\text { An examination of the rise in government surveillance through } \\
\text { mobile applications }\end{array}$ \\
\hline 19 & M & Maghdid et al. & 2020 & $P$ & Iraq & SN Computer Science & $\begin{array}{l}\text { A smartphone-enabled approach to manage COVID-19 lockdown } \\
\text { and economic crisis }\end{array}$ \\
\hline 20 & M & Li et al. & 2020 & $P$ & China & Lancet & $\begin{array}{l}\text { Active case finding and case management: the key to tackling the } \\
\text { COVID-19 pandemic }\end{array}$ \\
\hline 21 & $\mathrm{~S}$ & Guillon et al. & 2020 & E, Ps & France & Public Health & $\begin{array}{l}\text { Attitudes and opinions on quarantine and support for a } \\
\text { contact-tracing application in France during the } \\
\text { COVID-19 outbreak }\end{array}$ \\
\hline 22 & M & Hager et al. & 2020 & E, P & European Union & Int Political Sociolog & $\begin{array}{l}\text { Collective discussion: toward critical approaches to intelligence as } \\
\text { a social phenomenon }\end{array}$ \\
\hline 23 & M & Abuhammad et al. & 2020 & E, Ed, P & Jordan & Patient Preference and Adherence & $\begin{array}{l}\text { COVID-19 contact-tracing technology: acceptability and ethical } \\
\text { issues of use }\end{array}$ \\
\hline 24 & M & Reimer et al. & 2020 & E, P & Australia & Eur J Info Sys & Digital contact-tracing adoption in the COVID-19 pandemic \\
\hline 25 & M & Basu et al. & 2020 & E & India & Camb Quart Healthcare Ethics & Mobile phones and contact tracing \\
\hline 27 & W & Maati et al. & 2020 & E, $P$ & Germany & Czech J Int Relations & Framing the pandemic and the rise of the digital surveillance state \\
\hline 28 & M & Ekong et al. & 2020 & E, P & Nigeria & JMIR Mhealth Uhealth & $\begin{array}{l}\text { Mobile positioning data contact tracing and patient } \\
\text { privacy regulations }\end{array}$ \\
\hline 29 & M & Dong et al. & 2020 & E, Ps & China & J Med Internet Res & $\begin{array}{l}\text { Public emotions and rumors spread during the } \\
\text { COVID-19 epidemic }\end{array}$ \\
\hline 30 & S & Sfendla et al. & 2020 & Ps & Morocco & Health Secur & $\begin{array}{l}\text { Factors associated with psychological distress and physical } \\
\text { activity during the COVID-19 pandemic }\end{array}$ \\
\hline 31 & S & Smith et al. & 2020 & E, P & UK & Public Health & $\begin{array}{l}\text { Factors associated with adherence to self-isolation and lockdown } \\
\text { measures in the UK: a cross-sectional survey }\end{array}$ \\
\hline 32 & M & Shah et al. & 2020 & E & Nepal & Nepal Med Assoc & $\begin{array}{l}\text { Combating the COVID-19 pandemic in Nepal: Ethical challenges } \\
\text { in an outbreak }\end{array}$ \\
\hline 33 & M & O'Callaghan et al. & 2020 & E, P & Ireland & Ir J Med Sci & $\begin{array}{l}\text { A national survey of attitudes to COVID-19 digital contact tracing } \\
\text { in the Republic of Ireland }\end{array}$ \\
\hline 34 & M & Ye & 2020 & P, Ps & US & JMIR Pediatr Parent & $\begin{array}{l}\text { Pediatric mental and behavioral health in the period of } \\
\text { quarantine and social distancing with COVID-19 }\end{array}$ \\
\hline 35 & M & Rothstein & 2020 & E, P & US & J Law Med and Ethic & The coronavirus pandemic: public health and American values. \\
\hline
\end{tabular}


Table 1. Cont

\begin{tabular}{|c|c|c|c|c|c|c|c|}
\hline No. & Health Evidence & Author(s) & Year & Topic & Country & Journal & Subject \\
\hline 36 & M & Torous et al. & 2020 & P, Ps & US & JMIR Mental Health & $\begin{array}{l}\text { Digital mental health and COVID-19: using technology today to } \\
\text { accelerate the curve on access and quality tomorrow }\end{array}$ \\
\hline 37 & $\mathrm{~S}$ & Tambo et al. & 2020 & Ed, P & Cameron & Global Health J & $\begin{array}{l}\text { Early stage risk communication and community engagement } \\
\text { (RCCE) strategies and measures against the coronavirus disease } \\
2019 \text { (COVID-19) pandemic crisis }\end{array}$ \\
\hline 38 & $\mathrm{~W}$ & Simon & 2020 & E & USA & Survival & Subtle connections: pandemic and the authoritarian impulse \\
\hline 39 & $\mathrm{M}$ & EU & 2021 & $\mathrm{E}, \mathrm{P}$ & European Union & Commissioners' Office Web & Guide to the general data protection regulation (GDPR) \\
\hline 40 & M & Shuja & 2021 & $\mathrm{E}$ & Pakistan & Applied Intelligence & COVID-19 open source data sets \\
\hline 41 & M & Baumgart et al. & 2021 & Ed, P & Canada & NPI Digital Medicine & $\begin{array}{l}\text { Digital advantage in the COVID-19 response: perspective } \\
\text { from Canada }\end{array}$ \\
\hline 42 & M & Jacob et al. & 2021 & $\mathrm{P}$ & Canada & Policy design and practice & $\begin{array}{l}\text { The adoption of contact tracing applications for COVID-19 by the } \\
\text { European governments }\end{array}$ \\
\hline 43 & $\mathrm{~S}$ & Sowmiya et al. & 2021 & $\mathrm{E}$ & India & SN Computer Science & $\begin{array}{c}\text { A survey on security and privacy issues in contact } \\
\text { tracing applications }\end{array}$ \\
\hline 44 & $\mathrm{M}$ & Gerli et al. & 2021 & $\mathrm{P}$ & UK & Government Info Quarterly & The public value of eHealth application in a pandemic \\
\hline 45 & M & Niccolai et al. & 2021 & $\mathrm{P}$ & USA & AJPH & $\begin{array}{l}\text { Rapid establishment of a volunteer contact tracing program } \\
\text { for COVID-19 }\end{array}$ \\
\hline 47 & $\mathrm{M}$ & Hassandoust et al. & 2021 & Ed, $P$ & New Zealand & $J A M I A$ & $\begin{array}{l}\text { Individuals' privacy concerns and adoption of contact tracing } \\
\text { mobile applications in a pandemic }\end{array}$ \\
\hline 48 & $\mathrm{~S}$ & Bradshaw et al. & 2021 & Ps & Australia & Frontiers in Psychology & $\begin{array}{l}\text { The information safety assurance increases intentions to use } \\
\text { COVID-19 contact tracing applications }\end{array}$ \\
\hline 49 & M & Legendre et al. & 2021 & $\mathrm{P}$ & Switzerland & arXiv & Contact tracing technologies and cyber risks \\
\hline 50 & $\mathrm{~S}$ & CDC & 2021 & $\mathrm{P}$ & USA & Web & Contact tracing resources \\
\hline 51 & S & Williams et al. & 2021 & E, Ps & UK & Health Expectations & Public attitudes towards COVID-19 contact tracing apps \\
\hline 52 & S & Chen et al. & 2021 & P, Ps & USA & Geriatr Nurs & $\begin{array}{l}\text { Reactions to COVID-19, information and technology use, and } \\
\text { social connectedness among older adults with pre-frailty } \\
\text { and frailty }\end{array}$ \\
\hline
\end{tabular}




\section{Results}

The initial term use, Public Health Strategies, returned over 2 million hits in Google Scholar. Similar results were also obtained using other search engines. The search term was changed to "Public Health Strategies" to receive a lower and manageable number of references (Appendix A). Other keywords were added stepwisely, and the number of hits decreased consequently. A descriptive summary of the results from the conducted systematic literature review is presented in Figure 1 in a PRISMA flow chart format. More details regarding the reviewed studies are presented in Table 1, including the following information: (1) health evidence (classified as either Strong (S) or Medium (M) or Weak (W)); (2) author(s); (3) year; (4) journal; and (5) subject of the study. The following four topics were revealed through the content analysis: (1) practical aspects; (2) ethical aspects; (3) psychological aspects; and (4) educational initiatives at the community level. The insights regarding these topics are discussed in the following sections of the manuscript.

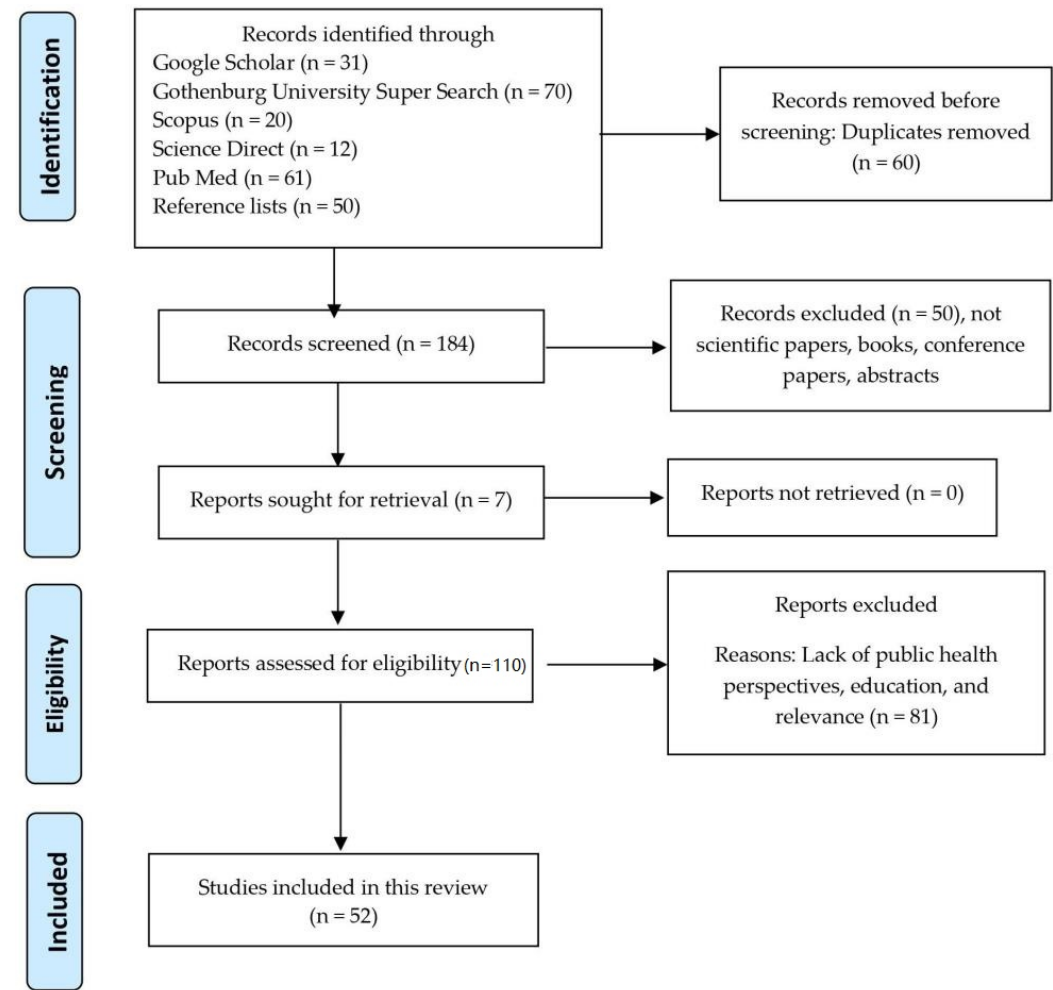

Figure 1. PRISMA 2020 flow diagram for new systematic reviews [44].

\subsection{Practical Aspects}

A practical app should enable the identification of people who not only belong to the participants' network but also those not known to them, such as fellow passengers on a bus. Working properly, a contact tracing app needs to comply with some technical requirements, of which the most important might be the need to operate at a close range. It is also important that many people use the technology to attain valid and accurate data. Some apps may prompt an individual who may have been in contact with a COVID-19 positive person to self-isolate [48].

Many different technological alternatives were discovered throughout the conducted systematic literature review, including GPS, Bluetooth, cellular location tracking, and QR codes, with a variety of practical and ethical concerns [49,50]. A GPS app, such as the one used in Korea, tracks the movement of people ordered to quarantine. However, the level of accuracy by which it traces contacts is around 10-20 m, which is not effective, particularly inside buildings. The precision of the cellular location data is even lower and poses significant concerns over the privacy of users. Some countries have used the QR 
codes to develop surveillance technologies. People are forced to scan their QR code doing certain activities (e.g., shopping, using public transportation) or when they enter into a new country. Although a QR-based system can efficiently control and restrict people's movement, it can neither determine whether there has been any close contact between an infected individual and another person, nor if they obey and follow the rules of social distancing measures in public $[49,50]$.

One promising solution, supported by the $\mathrm{EU}$, is the use of Bluetooth to track the population. One important characteristic of Bluetooth is its ability to operate effectively at a close range. This, in turn, would facilitate the development of an application that allows users to opt-in or out easily by simply turning their Bluetooth on or off. Besides contact tracing, Bluetooth can also hypothetically help to control and measure whether the public respects the guidelines of social distancing. An important characteristic of Bluetooth, in contrast to other forms of cellular data, is its ability to function with an acceptable degree of accuracy at around $2 \mathrm{~m}$. Consequently, its effective administration and utilization would potentially facilitate a faster return to normalcy $[8,9,49,50]$.

Simple and safe technology can contribute to an increased willingness and ability of people to participate and thus increase the reliability and impact of the system. In Sweden, the number of people over 18 years having a smartphone is around 6.7 million. A total of 187,139 people had downloaded the recommended COVID-19 contact tracing app, introduced on April 29 by the end of July 2020 (2.8\%) [17], while other countries have reported a higher number of participants (37\%). However, these numbers are significantly lower than the recommended $65-70 \%$ to cover the necessary area and deliver a reliable result [50].

\subsection{Ethical Aspects}

Emerging evidence from some EU countries, most affected by the current pandemic, suggests that they use aggregated call detail records (CDRs) to carry out their stay-at-home policies and implementation of lockdowns $[4,6,24,51]$. In addition, there are other valid ethical concerns regarding the use of contact tracing apps within the EU, challenging its General Data Protection Regulation (GDPR).

According to the GDPR regulation, people have the possibility of using their rights in not disclosing whom they have been in contact with or can legally resist and challenge the tracking by authorities $[7,19,22,35]$. Furthermore, critics of contact tracing have pointed out that most of the apps are inconsistent with a range of older Android devices. Potentially, this inconsistency jeopardizes and influences the most vulnerable groups since elderly and poor citizens cannot use the new technology and lack the needed financial support to get one. There is also a lack of a mechanism to opt-in or opt-out of the third-party trackers in most used systems.

There has been a discussion regarding the pros and cons of a centralized vs. decentralized data collection system. In a centralized model, the process of matching occurs on a computer server, while in a decentralized model, the exchange takes place on people's devices. Some claim that the relevant authorities will hold the data for a short period and handle it according to the highest ethical and security standards. However, there are reports arguing the necessity of undertaking a transparent Data Protection Impact Assessment (DPIA) before processing any personal data since data needs to be shared because of its nature. According to the EU Data Protection Watchdog, one of the requirements for using a Bluetooth app is to ensure its 'privacy-by-design'. Finally, there is a need for a new legislation to facilitate and safeguard a return to normalcy once the crisis is over to guarantee the public trust enough to consider joining such mass surveillance strategies [7-9,51,52].

\subsection{Psychological Aspects}

The practical concerns about using apps may also get more complicated with the psychology behind using (or not using) any apps [53-59]. In a recent publication, Williams et al. [53] reported that the participants in their study were not sure whether using digital 
contact tracing was a good idea. Their moral reasoning and beliefs strongly influenced their standpoints. There were several themes in their reasoning, such as lack of information and misconceptions around the COVID-19 tracing app, concerns over privacy, stigma, and uptake, and contact tracing as a benefit for the population. These factors, particularly the concerns over privacy, stigma, and uptake, may create a psychological defense barrier for the willingness of using the app. Another Irish study confirmed the results from the UK, although the public willingness to download and use the app in that study was twice as high $[53,59]$.

The use of new technologies and its impact on individuals may differ due to age or underlying medical and psychological conditions, and may include difficulties in the adoption of precautionary measures and altered daily routines. In one study, for instance, although the information and technology use kept the participants informed and connected, they experienced negative emotional consequences, including stress, worry, and anxiety, and reported varying degrees of preparedness [54]. In addition, rumors spread may influence public's emotions, increasing their anxiety and anger [55]. Furthermore, isolation and quarantine during the pandemic seem to be associated with interpersonal sensitivity, somatization, and distress, especially symptoms like suspiciousness, hostility, and fearful thoughts of losing autonomy as well as feelings of inadequacy, uneasiness, and discomfort during interpersonal interactions [56]. All these issues result in poor adherence to selfisolation, contact tracing, and obeying recommendations [57].

\subsection{Educational Initiatives at the Community Level}

Although there are some variations in rate, over $75 \%$ of the populations within different EU countries have downloaded contact tracing apps. It is, however, not clear whether the intent to download corresponds to the actual download and use of the app [59]. Having in mind that information is a necessary part of the implementation process of new ideas and technology, particularly those of global interests, the need for educational initiatives to enable correct understanding of the use and benefits associated with the technologies is undeniable.

Previous studies concerning the $2009 \mathrm{H} 1 \mathrm{~N} 1$ pandemic response have indicated that the primary barrier to successful management, besides overcrowding in houses, insufficient human resources, and the lack in local surveillance, is the inadequate community awareness regarding disease processes and prevention [60,61]. Other studies have also shown that adding community specific details, such as information about supplies and resources and details of how, when, where, and who has the responsibility for implementing recommendations outlined in the pandemic plans, together with the roles and responsibilities of the involved organizations, are essential elements in a pandemic plan and guarantee a successful outcome [62]. Irrespective of cultural and traditional background of each community, there have been successful efforts in low- and middle-income countries to engage and mobilize community members in case-detection and reduce the extent of infectious disease by establishing community-based strategies, including workshops and the use of social media [63]. One major facilitator for community engagement today is the use of new technology. Digital approaches, health technologies, and informatics might be used to inform all community members of the scale and development of pandemic, while they may also be designed and implemented to support public health surveillance and critical responses to adults' and children's well-being [64].

While a successful app should have certain grades of quality, security, privacy, defined usability, and compatibility, it is equally important that its need is matched to consumers' general and health literacy levels. Kim and Park presented the concept of the health information technology acceptance model in 2012 (Figure 2) [65]. According to this model, each individual has three concern zones which influence individuals' acceptance of technologies such as contact tracing apps. These are health concerns, information concerns, and technical concerns. All these concerns may influence an individual to accept or deny the use of an application. Within the health zone, the primary factor that influences the use of 
the app is how individuals perceive the usefulness of the app to their health. The result of the perceived threats creates a psychological incitement for using the new technology. Within the information zone, there are two primary factors: subjective norms and the technology's credibility. The former is important for behavioral induction and consists of social pressure and community competition, i.e., the signals an individual receives from the surrounding networks about the society's standing in accepting and using the new technology. Therefore, within the health technology, social networking is used to change consumers' behavior and to predict their attitudes. Finally, factors, such as output quality, result demonstrability, objective usability, and perceived enjoyment, all demonstrating technological superiority, result in perceived ease of use and increased motivation for the use of an app [65].

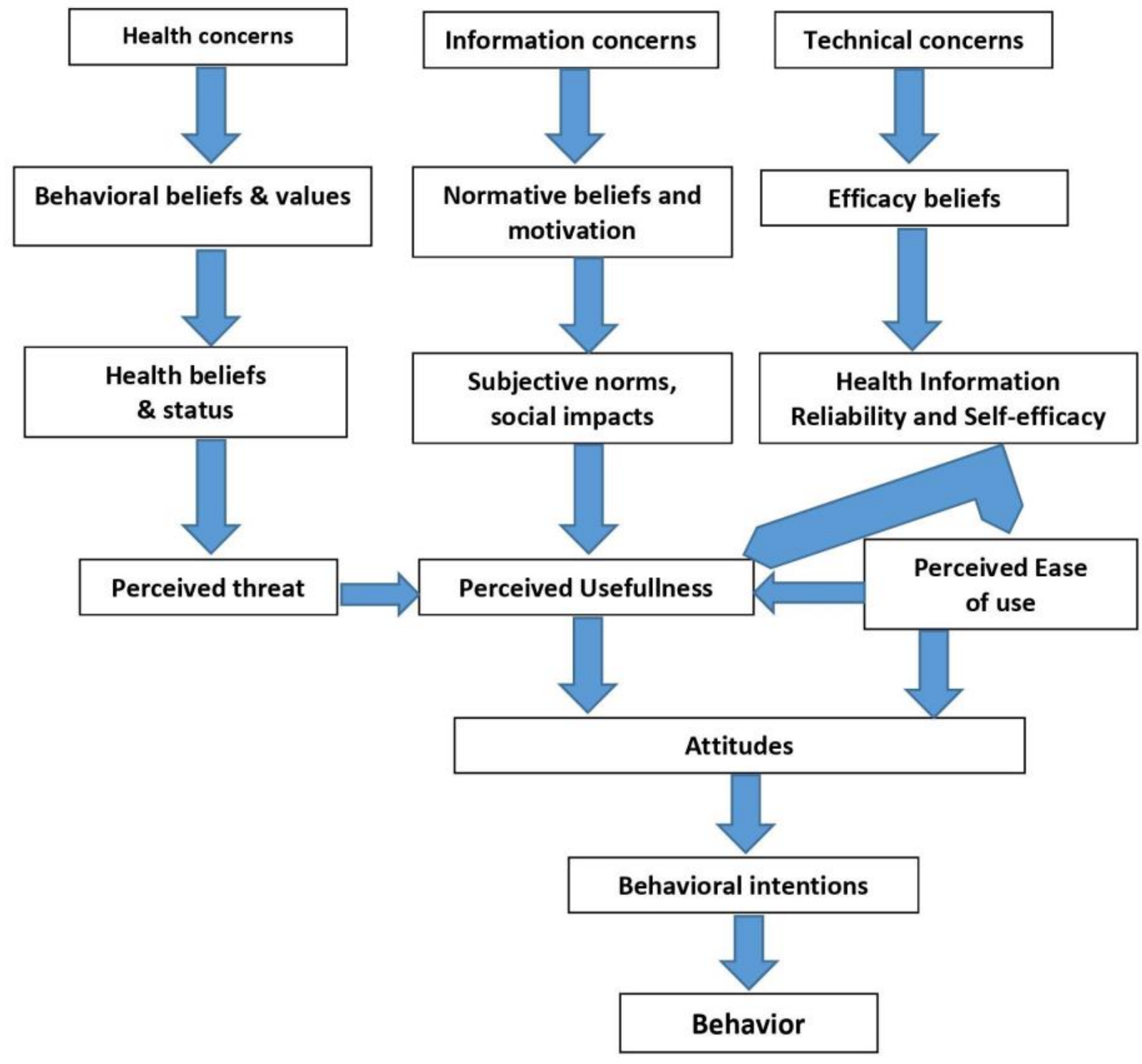

Figure 2. Health information technology acceptance model [65].

\section{Discussion}

The efficiency of contact tracing in any form depends on the public's willingness to participate and collaborate with the authorities. Such collaboration depends on the trust they have in the government regarding the safety and security measures they impose to protect their private lives and identity. Nowadays, societies with advanced and developed infrastructure are equally affected by the pandemic and might be the first victims $[1,3,29-31]$. 
One significant characteristic for these societies is their share in technical instruments and devices utilization. Mobile phones, Bluetooth, GPS, etc. not only enable social networking but also create ethical and psychological dilemmas that need to be discussed if using them as digital public health measures.

The current pandemic manifested at an accelerating rate and created a condition when the lack of specific treatment and vaccine necessitated the implementation of public health strategies. Such strategies may vary due to the cause of outbreak, but in a pandemic, may constitute social distancing, contact tracing, personal protective equipment, isolation, and quarantine [66]. Although the implementation of these strategies might be inevitable, they may create societal and human rights issues, which would yield to inadequate levels of compliance and different outcomes in various nations [12,40]. For instance, the social acceptance of implementing public health strategies has differed between Canada and the USA. The former is known as the home of social solidarity and the latter is known as a nation with rugged individualism, self-reliance, nonconformity, and independence [67]. Although social restrictions might be one of the main reasons for disobeying public health recommendations, other factors, such as housing, transportation, education, employment, food, and other household needs, are all crucial needs of persons under public health surveillance. Addressing these factors will increase individual willingness to comply with voluntary and mandated public health measures such as quarantine [68].

Technical requirements that include opt-in measures are necessary to grant contact tracing app users the ability to return to their normal lives in an achievable time, provided they use the app and respect other important public health measures. This would comply with the European Data Protection Board (EDPB)'s statement that restrictions of freedom during the pandemic or any other emergency during a strictly limited period are acceptable [31,32]. A solely Bluetooth-enabled app would operate on a system of individual anonymous codes, which enables the exchange of codes through a decentralized system. It gives users the most control over their data and should help them prevent the potential privacy conflicts that might arise if governments were to monitor the location data by teaming up with the relevant service providers such as Google. However, the Bluetooth technology still has its limitations.

The current COVID-19 pandemic and the development and deployment of digital public health technologies have initiated efforts to produce scientific and ethical sound guidelines and policies to guarantee personal information safety and ensure widespread public trust and uptake. Since ethical and legal aspects of using such technologies are also main concerns, one measure could be to conduct an ethical-legal analysis of these concepts with procedural considerations in technology governance. Such an approach may result in guidelines, navigation aids, or other algorithms that might help decision makers to ensure procedural validity and minimize ethical issues and shortcomings during the development or deployment of digital public health technologies [33].

Irrespective of all quality controls and information that may eliminate misconceptions, an improvement in psychology and an increase in the understanding of app utilization should be the first steps in using any apps, including contact tracing apps. Moreover, consumers should be educated regarding the content, benefits, and harms of these apps $[69,70]$. This approach would increase the perceived usefulness and ease of use but also indirectly increase the awareness of individuals in detecting new threats. Several reports have indicated that people with lower health literacy have worse healthcare and poorer health outcomes. They simply lack the skills necessary to manage their health and participate in disease prevention actively [71,72]. Previous studies in different parts of the world have shown that low or limited health literacy in the US, Southeast Asia, and the European Union are prevalent and consistently associated with several factors such as education, ethnicity, and age. In Europe, one in every two Europeans may not be able to comprehend essential health-related information and materials [72-75].

Key components necessary for the preparation of a community to combat emergencies are those of risk communication and community engagement strategies at the early stages. 
Preventive and emergency response strategies should be coordinated and strengthened at the community level by improving community resilience and through educational initiatives. The crucial steps in achieving a resilient and knowledgeable community are a transparent and trustful government-people relationship, improved health systems security proactivity, community to individual confinement, trust, and resilient solutions $[76,77]$.

Furthermore, it is equally necessary that those working within the field of information privacy and security accommodate the public demands and protect their rights to privacy. A future public health emergency may not facilitate any option to adopt such mass surveillance measures [32]. It is, thus, crucial to ensure that policies, mathematical models, and technological measures are developed and in place to protect the collected and used data and promote transparency in how data can help contain the spread of disease while protecting and ensuring civil liberties [31].

\section{Limitations}

The main limitation of this study is its focus on the published literature in English. Consequently, relevant information in other languages may be missing. The criteria used to narrow the selection of included publications enabled the authors to access eligible data and a feasible number of publications to handle the content analysis and to perform the review. However, the criteria used may have been too selective, resulting in missing information. These limitations can be further addressed as a part of the future research.

\section{Conclusions}

A public health situation becomes an emergency when its scale, timing, or unpredictability have the potential to overwhelm routine capabilities. Such a definition necessitates an all-hazards approach to preparedness, allows for the optimal development of capabilities across scenarios, and better prepares communities for a broad spectrum of potential risks [1,78]. As public health emergencies, in general, and pandemics, in particular, are on the rise, the use of technologies in future communicable diseases might be inevitable. However, it is evident that there are some practical, psychological, and ethical challenges that need to be resolved before future public health policy planning [33]. The implementation of public health strategies, in the absence of appropriate treatment or vaccine, demands higher public health knowledge to recognize, accept, and deal with all restrictions and concerns. Besides educational initiatives at all levels of the society, particularly at the community levels, policy makers should also be prudent in evaluating the risk and benefits of using such technologies while technicians should determine how new generation technologies could be effectively adjusted to increase the public trust when using various technology-based public health strategies in increasing global disorder.

Author Contributions: A.K.-M. provided the main framework, identified, and organized primary materials, and collaborated in writing the manuscript. K.G. identified appropriate references and collaborated on the writing of the manuscript. M.A.D. contributed to drafting sections of the manuscript. All authors have read and agreed to the published version of the manuscript.

Funding: This research received no external funding.

Institutional Review Board Statement: Not applicable.

Informed Consent Statement: Not applicable.

Data Availability Statement: Datasets used and analyzed during the current study are presented as Appendices A-D.

Conflicts of Interest: The authors declare no conflict of interest. 
Appendix A. Searching Procedures

\begin{tabular}{|c|c|c|}
\hline Search Engine & Searching Keywords & Hits \\
\hline \multirow{7}{*}{$\begin{array}{l}\text { Google Scholar } \\
\text { Reviewed } 31 \text { Duplicates 10, Irrelevant 19, } \\
\text { Included } 12\end{array}$} & Public Health Strategies & $>4$ million \\
\hline & "Public Health Strategies" & 21,000 \\
\hline & $\begin{array}{l}\text { "Public Health emergency" AND [(Contact Tracing) OR (Isolation) OR } \\
\text { (Quarantine)] }\end{array}$ & 31,100 \\
\hline & $\begin{array}{l}\text { "Public Health emergency" AND "[(Contact Tracing) OR (Isolation) OR } \\
\text { (Quarantine)]" }\end{array}$ & 6690 \\
\hline & $\begin{array}{l}\text { "Public Health emergency" AND “Contact Tracing" AND "Isolation" AND } \\
\text { "Quarantine" AND Public Education }\end{array}$ & 2850 \\
\hline & $\begin{array}{l}\text { "Public Health emergency" AND "[(Contact Tracing) OR (Isolation) OR } \\
\text { (Quarantine)]" AND "Public Education" }\end{array}$ & 354 \\
\hline & $\begin{array}{l}\text { "Public Health emergency" AND "[(Contact Tracing) OR (Isolation) OR } \\
\text { (Quarantine)]" AND "Public Education" AND "Community resilience" }\end{array}$ & 31 \\
\hline \multirow{5}{*}{$\begin{array}{l}\text { Gothenburg University Super Search } \\
\text { Reviewed } 70 \text { Duplicates 50, Irrelevant 15, } \\
\text { Included } 7\end{array}$} & "Public Health emergency" AND “Contact Tracing" & 2281 \\
\hline & "Public Health emergency" AND "Contact Tracing" AND "Isolation" & 1223 \\
\hline & $\begin{array}{l}\text { "Public Health emergency" AND “Contact Tracing" AND "Isolation" AND } \\
\text { "Quarantine" }\end{array}$ & 803 \\
\hline & $\begin{array}{l}\text { "Public Health emergency" AND "Contact Tracing" AND "Isolation" AND } \\
\text { "Quarantine" AND Public Education }\end{array}$ & 437 \\
\hline & $\begin{array}{l}\text { "Public Health emergency" AND “Contact Tracing" AND "Isolation" AND } \\
\text { "Quarantine" AND "Public Education" }\end{array}$ & 70 \\
\hline \multirow{5}{*}{$\begin{array}{l}\text { Science Direct } \\
\text { Reviewed 15, Irrelevant 10, Included } 5\end{array}$} & $\begin{array}{l}\text { "Public Health emergency" AND [(Contact Tracing) OR (Isolation) OR } \\
\text { (Quarantine)] }\end{array}$ & 456 \\
\hline & $\begin{array}{l}\text { "Public Health emergency" AND “[(Contact Tracing) OR (Isolation) OR } \\
\text { (Quarantine)]" }\end{array}$ & 313 \\
\hline & $\begin{array}{l}\text { "Public Health emergency" AND "[(Contact Tracing) OR (Isolation) OR } \\
\text { (Quarantine)]" AND Public Education }\end{array}$ & 218 \\
\hline & $\begin{array}{l}\text { "Public Health emergency" AND "[(Contact Tracing) OR (Isolation) OR } \\
\text { (Quarantine)]" AND "Public Education" }\end{array}$ & 113 \\
\hline & $\begin{array}{l}\text { "Public Health emergency" AND "Contact Tracing" AND "Isolation" AND } \\
\text { "Quarantine" AND Public Education }\end{array}$ & 15 \\
\hline \multirow{5}{*}{$\begin{array}{l}\text { Scopus } \\
\text { Reviewed 20, Irrelevant 13, Included } 8\end{array}$} & "Public Health emergency" AND “Contact Tracing" & 286 \\
\hline & "Public Health emergency" AND “Contact Tracing" AND "Isolation" & 117 \\
\hline & $\begin{array}{l}\text { "Public Health emergency" AND “Contact Tracing" AND "Isolation" AND } \\
\text { "Quarantine" }\end{array}$ & 63 \\
\hline & $\begin{array}{l}\text { "Public Health emergency" AND "Contact Tracing" AND "Isolation" AND } \\
\text { "Quarantine" AND Public Education }\end{array}$ & 20 \\
\hline & $\begin{array}{l}\text { "Public Health emergency" AND “Contact Tracing" AND "Isolation" AND } \\
\text { "Quarantine" AND "Public Education" }\end{array}$ & 0 \\
\hline \multirow{4}{*}{$\begin{array}{l}\text { PubMed } \\
\text { Reviewed 61, Irrelevant 33, Included } 15\end{array}$} & $\begin{array}{l}\text { "Public Health emergency" AND [(Contact Tracing) OR (Isolation) OR } \\
\text { (Quarantine)] }\end{array}$ & $>2$ million \\
\hline & $\begin{array}{l}\text { "Public Health emergency" AND "[(Contact Tracing) OR (Isolation) OR } \\
\text { (Quarantine)]" }\end{array}$ & 466 \\
\hline & $\begin{array}{l}\text { "Public Health emergency" AND “[(Contact Tracing) OR (Isolation) OR } \\
\text { (Quarantine)]" AND Public Education }\end{array}$ & 62 \\
\hline & $\begin{array}{l}\text { "Public Health emergency" AND "[(Contact Tracing) OR (Isolation) OR } \\
\text { (Quarantine)]" AND "Public Education" }\end{array}$ & 0 \\
\hline
\end{tabular}


Appendix B. PRISMA Checklist Abstract

\begin{tabular}{|c|c|c|c|}
\hline Section and Topic & Item Number & Checklist Item & Reported (Yes/No) \\
\hline \multicolumn{4}{|l|}{ TITLE } \\
\hline Title & 1 & Identify the report as a systematic review. & YES \\
\hline \multicolumn{4}{|l|}{ BACKGROUND } \\
\hline Objectives & 2 & $\begin{array}{l}\text { Provide an explicit statement of the main objective(s) or question(s) the } \\
\text { review addresses. }\end{array}$ & YES \\
\hline \multicolumn{4}{|l|}{ METHODS } \\
\hline Eligibility criteria & 3 & Specify the inclusion and exclusion criteria for the review. & YES \\
\hline Information sources & 4 & $\begin{array}{l}\text { Specify the information sources (e.g., databases, registers) used to identify } \\
\text { studies and the date when each was last searched. }\end{array}$ & YES \\
\hline Risk of bias & 5 & Specify the methods used to assess risk of bias in the included studies. & No \\
\hline Synthesis of results & 6 & Specify the methods used to present and synthesise results. & No \\
\hline \multicolumn{4}{|l|}{ RESULTS } \\
\hline Included studies & 7 & $\begin{array}{l}\text { Give the total number of included studies and participants and summarise } \\
\text { relevant characteristics of studies. }\end{array}$ & No \\
\hline Synthesis of results & 8 & $\begin{array}{l}\text { Present results for main outcomes, preferably indicating the number of } \\
\text { included studies and participants for each. If meta-analysis was done, } \\
\text { report the summary estimate and confidence/credible interval. If } \\
\text { comparing groups, indicate the direction of the effect (i.e., which group } \\
\text { is favoured). }\end{array}$ & YES \\
\hline \multicolumn{4}{|l|}{ DISCUSSION } \\
\hline Limitations of evidence & 9 & $\begin{array}{l}\text { Provide a brief summary of the limitations of the evidence included in the } \\
\text { review (e.g., study risk of bias, inconsistency and imprecision). }\end{array}$ & YES \\
\hline Interpretation & 10 & Provide a general interpretation of the results and important implications. & No \\
\hline \multicolumn{4}{|l|}{ OTHER } \\
\hline Funding & 11 & Specify the primary source of funding for the review. & None \\
\hline Registration & 12 & Provide the register name and registration number. & None \\
\hline
\end{tabular}

From: Page M.J., McKenzie J.E., Bossuyt P.M., Boutron I., Hoffmann T.C., Mulrow C.D., et al. The PRISMA 2020 statement: an updated guideline for reporting systematic reviews. BMJ 2021;372:n71. doi:10.1136/bmj.n71.

Appendix C. PRISMA Checklist Manuscript

\begin{tabular}{|c|c|c|c|}
\hline Section and Topic & $\begin{array}{l}\text { Item } \\
\text { Number }\end{array}$ & Checklist Item & $\begin{array}{l}\text { Location Where Item } \\
\text { Is Reported }\end{array}$ \\
\hline \multicolumn{4}{|l|}{ TITLE } \\
\hline Title & 1 & $\begin{array}{l}\text { Implementing contact tracing and other public health strategies; needs } \\
\text { for educational initiatives-A Systematic Review }\end{array}$ & Page 1 \\
\hline \multicolumn{4}{|l|}{ ABSTRACT } \\
\hline Abstract & 2 & See the PRISMA 2020 for Abstracts checklist. & Page 1 \\
\hline \multicolumn{4}{|l|}{ INTRODUCTION } \\
\hline Rationale & 3 & Describe the rationale for the review in the context of existing knowledge. & Page $1-3$ \\
\hline Objectives & 4 & $\begin{array}{l}\text { Provide an explicit statement of the objective(s) or question(s) the review } \\
\text { addresses. }\end{array}$ & Page $1 \& 3$ \\
\hline \multicolumn{4}{|l|}{ METHODS } \\
\hline Eligibility criteria & 5 & $\begin{array}{l}\text { Specify the inclusion and exclusion criteria for the review and how studies } \\
\text { were grouped for the syntheses. }\end{array}$ & Method page 2-3 \\
\hline Information sources & 6 & $\begin{array}{l}\text { Specify all databases, registers, websites, organisations, reference lists and } \\
\text { other sources searched or consulted to identify studies. Specify the date } \\
\text { when each source was last searched or consulted. }\end{array}$ & Method page 2 \\
\hline
\end{tabular}




\begin{tabular}{llll}
\hline Section and Topic & $\begin{array}{l}\text { Item } \\
\text { Number }\end{array}$ & Checklist Item & $\begin{array}{l}\text { Location Where Item } \\
\text { Is Reported }\end{array}$ \\
\hline Search strategy & 7 & $\begin{array}{l}\text { Present the full search strategies for all databases, registers and websites, } \\
\text { including any filters and limits used. }\end{array}$ & Appendix. \\
\hline Selection process & 8 & $\begin{array}{l}\text { Specify the methods used to decide whether a study met the inclusion } \\
\text { criteria of the review, including how many reviewers screened each record } \\
\text { and each report retrieved, whether they worked independently, and if } \\
\text { applicable, details of automation tools used in the process. }\end{array}$ & Method page 2-3 \\
\hline
\end{tabular}
applicable, details of automation tools used in the process.

Data collection process

9

Data items
Specify the methods used to collect data from reports, including how many reviewers collected data from each report, whether they worked independently, any processes for obtaining or confirming data from study investigators, and if applicable, details of automation tools used in the process.

List and define all outcomes for which data were sought. Specify whether all results that were compatible with each outcome domain in each study were sought (e.g., for all measures, time points, analyses), and if not, the methods used to decide which results to collect.
Method page 2-3

Figure 1 page 4 , Table 1 , page 5

List and define all other variables for which data were sought (e.g., participant and intervention characteristics, funding sources). Describe any See point 10a assumptions made about any missing or unclear information.

Specify the methods used to assess risk of bias in the included studies,

Study risk of bias including details of the tool(s) used, how many reviewers assessed each assessment study and whether they worked independently, and if applicable, details of

Method page 2-3 automation tools used in the process.

\begin{tabular}{|c|c|c|c|}
\hline Effect measures & 12 & $\begin{array}{l}\text { Specify for each outcome the effect measure(s) (e.g., risk ratio, mean } \\
\text { difference) used in the synthesis or presentation of results. }\end{array}$ & NA \\
\hline \multirow{6}{*}{ Synthesis methods } & $13 a$ & $\begin{array}{l}\text { Describe the processes used to decide which studies were eligible for each } \\
\text { synthesis (e.g., tabulating the study intervention characteristics and } \\
\text { comparing against the planned groups for each synthesis (item \#5)). }\end{array}$ & Result page 3-4 \\
\hline & $13 b$ & $\begin{array}{l}\text { Describe any methods required to prepare the data for presentation or } \\
\text { synthesis, such as handling of missing summary statistics, or data } \\
\text { conversions. }\end{array}$ & NA \\
\hline & $13 c$ & $\begin{array}{l}\text { Describe any methods used to tabulate or visually display results of } \\
\text { individual studies and syntheses. }\end{array}$ & - \\
\hline & $13 d$ & $\begin{array}{l}\text { Describe any methods used to synthesize results and provide a rationale for } \\
\text { the choice(s). If meta-analysis was performed, describe the model(s), } \\
\text { method(s) to identify the presence and extent of statistical heterogeneity, } \\
\text { and software package(s) used. }\end{array}$ & Method page $2-3$ \\
\hline & $13 \mathrm{e}$ & $\begin{array}{l}\text { Describe any methods used to explore possible causes of heterogeneity } \\
\text { among study results (e.g., subgroup analysis, meta-regression). }\end{array}$ & - \\
\hline & $13 \mathrm{f}$ & $\begin{array}{l}\text { Describe any sensitivity analyses conducted to assess robustness of the } \\
\text { synthesized results. }\end{array}$ & - \\
\hline $\begin{array}{l}\text { Reporting bias } \\
\text { assessment }\end{array}$ & 14 & $\begin{array}{l}\text { Describe any methods used to assess risk of bias due to missing results in a } \\
\text { synthesis (arising from reporting biases). }\end{array}$ & - \\
\hline \multirow{2}{*}{ Certainty assessment } & \multirow{2}{*}{15} & \multirow{2}{*}{$\begin{array}{l}\text { Describe any methods used to assess certainty (or confidence) in the body of } \\
\text { evidence for an outcome. }\end{array}$} & Method page 2 \\
\hline & & & HEQAT \\
\hline \multicolumn{4}{|l|}{ RESULTS } \\
\hline \multirow[t]{2}{*}{ Study selection } & $16 a$ & $\begin{array}{l}\text { Describe the results of the search and selection process, from the number of } \\
\text { records identified in the search to the number of studies included in the } \\
\text { review, ideally using a flow diagram. }\end{array}$ & Results, Page 3 \\
\hline & $16 b$ & $\begin{array}{l}\text { Cite studies that might appear to meet the inclusion criteria, but which were } \\
\text { excluded, and explain why they were excluded. }\end{array}$ & Figure 1 \\
\hline Study characteristics & 17 & Cite each included study and present its characteristics. & Page 5-7 \\
\hline Risk of bias in studies & 18 & Present assessments of risk of bias for each included study. & - \\
\hline $\begin{array}{l}\text { Results of individual } \\
\text { studies }\end{array}$ & 19 & $\begin{array}{l}\text { For all outcomes, present, for each study: (a) summary statistics for each } \\
\text { group (where appropriate) and (b) an effect estimate and its precision (e.g., } \\
\text { confidence/credible interval), ideally using structured tables or plots. }\end{array}$ & - \\
\hline
\end{tabular}




\begin{tabular}{|c|c|c|c|}
\hline Section and Topic & $\begin{array}{l}\text { Item } \\
\text { Number }\end{array}$ & Checklist Item & $\begin{array}{l}\text { Location Where Item } \\
\text { Is Reported }\end{array}$ \\
\hline \multirow{4}{*}{ Results of syntheses } & $20 \mathrm{a}$ & $\begin{array}{l}\text { For each synthesis, briefly summarise the characteristics and risk of bias } \\
\text { among contributing studies. }\end{array}$ & - \\
\hline & $20 \mathrm{~b}$ & $\begin{array}{l}\text { Present results of all statistical syntheses conducted. If meta-analysis was } \\
\text { done, present for each the summary estimate and its precision (e.g., } \\
\text { confidence/credible interval) and measures of statistical heterogeneity. If } \\
\text { comparing groups, describe the direction of the effect. }\end{array}$ & - \\
\hline & $20 \mathrm{c}$ & $\begin{array}{l}\text { Present results of all investigations of possible causes of heterogeneity } \\
\text { among study results. }\end{array}$ & - \\
\hline & $20 \mathrm{~d}$ & $\begin{array}{l}\text { Present results of all sensitivity analyses conducted to assess the robustness } \\
\text { of the synthesized results. }\end{array}$ & - \\
\hline Reporting biases & 21 & $\begin{array}{l}\text { Present assessments of risk of bias due to missing results (arising from } \\
\text { reporting biases) for each synthesis assessed. }\end{array}$ & - \\
\hline Certainty of evidence & 22 & $\begin{array}{l}\text { Present assessments of certainty (or confidence) in the body of evidence for } \\
\text { each outcome assessed. }\end{array}$ & Table 1, page $5-7$ \\
\hline \multicolumn{4}{|l|}{ DISCUSSION } \\
\hline \multirow{4}{*}{ Discussion } & $23 a$ & $\begin{array}{l}\text { Provide a general interpretation of the results in the context of other } \\
\text { evidence. }\end{array}$ & Page 9-11 \\
\hline & $23 \mathrm{~b}$ & Discuss any limitations of the evidence included in the review. & Page 9-11 \\
\hline & $23 \mathrm{c}$ & Discuss any limitations of the review processes used. & Page 9-11 \\
\hline & $23 \mathrm{~d}$ & Discuss implications of the results for practice, policy, and future research. & Page 9-11 \\
\hline \multicolumn{4}{|c|}{ OTHER INFORMATION } \\
\hline \multirow{3}{*}{$\begin{array}{l}\text { Registration and } \\
\text { protocol }\end{array}$} & $24 a$ & $\begin{array}{l}\text { Provide registration information for the review, including register name and } \\
\text { registration number, or state that the review was not registered. }\end{array}$ & Page 11 \\
\hline & $24 \mathrm{~b}$ & $\begin{array}{l}\text { Indicate where the review protocol can be accessed, or state that a protocol } \\
\text { was not prepared. }\end{array}$ & Journals homepage \\
\hline & $24 \mathrm{c}$ & $\begin{array}{l}\text { Describe and explain any amendments to information provided at } \\
\text { registration or in the protocol. }\end{array}$ & - \\
\hline Support & 25 & $\begin{array}{l}\text { Describe sources of financial or non-financial support for the review, and } \\
\text { the role of the funders or sponsors in the review. }\end{array}$ & None \\
\hline Competing interests & 26 & Declare any competing interests of review authors. & None \\
\hline $\begin{array}{l}\text { Availability of data, } \\
\text { code and other } \\
\text { materials }\end{array}$ & 27 & $\begin{array}{l}\text { Report which of the following are publicly available and where they can be } \\
\text { found: template data collection forms; data extracted from included studies; } \\
\text { data used for all analyses; analytic code; any other materials used in } \\
\text { the review. }\end{array}$ & Journals homepage \\
\hline
\end{tabular}

From: Page M.J., McKenzie J.E., Bossuyt P.M., Boutron I., Hoffmann T.C., Mulrow C.D., et al. The PRISMA 2020 statement: an updated guideline for reporting systematic reviews. BMJ 2021;372:n71. doi:10.1136/bmj.n71. For more information, visit: http://www.prisma-statement.org/ (accessed on 25 April 2021). 
Appendix D

\section{Health Evidence ${ }^{\text {TM }}$

Instructions for completion:

Please refer to the attached dictionary for definition of terms and instructions for completing each section. For each criteria, score by placing a check mark in the appropriate box.
First Author:
Year:
Journal:

Reviewer:

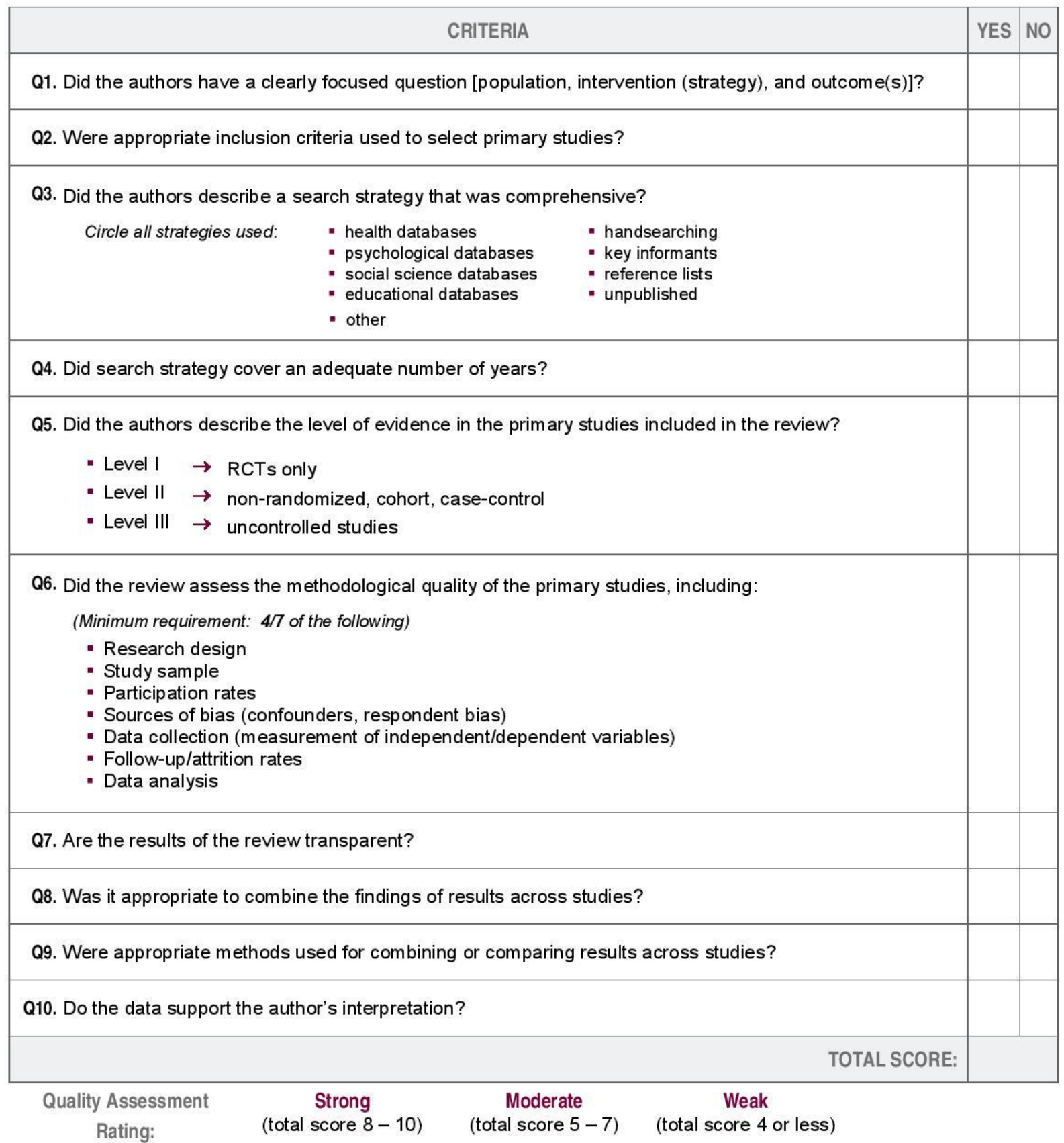




\section{References}

1. Humanitarian and Development Research Initiative (HADRI). State Responses to COVID-19: A Global Snapshot at 1 June 2020; Georgeou, N., Hawksley, C., Eds.; Western Sydney University: Sydney, Australia, 2020. [CrossRef]

2. Capano, G.; Howlett, M.; Jarvis, D.S.; Ramesh, M.; Goyal, N. Mobilizing Policy (In)Capacity to Fight COVID-19: Understanding Variations in State Responses. Policy Soc. 2020, 39, 285-308. [CrossRef]

3. Khorram-Manesh, A.; Carlström, E.; Hertelendy, A.J.; Goniewicz, K.; Casady, C.B.; Burkle, F.M. Does the prosperity of a country play a role in COVID-19 outcomes? Disaster Med. Public Health Prep. 2020, 1-20. [CrossRef]

4. Alanezi, F.; Aljahdali, A.; Alyousef, S.; Alrashed, H.; Mushcab, H.; AlThani, B.; Alghamedy, F.; Alotaibi, H.; Saadah, A.; Alanzi, T. A Comparative Study on the Strategies Adopted by the United Kingdom, India, China, Italy, and Saudi Arabia to Contain the Spread of the COVID-19 Pandemic. J. Healthc. Leadersh. 2020, 12, 117-131. [CrossRef]

5. Ferguson, N.; Laydon, D.; Nedjati-Gilani, G.; Imai, N.; Ainslie, K.; Baguelin, M.; Imperial College COVID-19 Response Team. Impact of Nonpharmaceutical Interventions (NPIs) to Reduce COVID19 Mortality and Healthcare Demand; Imperial College: London, UK, 2020; pp. 1-20.

6. Nazareth, J.; Minhas, J.; Jenkins, D.R.; Sahota, A.; Khunti, K.; Haldar, P.; Pareek, M. Early lessons from a second COVID-19 lockdown in Leicester, UK. Lancet 2020, 396, e4-e5. [CrossRef]

7. Abeler, J.; Bäcker, M.; Buermeyer, U.; Zillessen, H. COVID-19 Contact Tracing and Data Protection Can Go Together. JMIR mHealth uHealth 2020, 8, e19359. [CrossRef] [PubMed]

8. Hernandez-Quevedo, C.; Scarpetti, G.; Webb, E. How Do Countries Structure Contact Tracing Operations and What Is the Role of Apps? The Health System Response Monitor. Covid-19. Available online: https://analysis.covid19healthsystem.org/index.php/ 2020/06/18/how-do-countries-structure-contact-tracing-operations-and-what-is-the-role-of-apps/ (accessed on 25 April 2021).

9. Howell O'Neill, P.; Ryan-Mosley, T.; Johnson, B. A Flood of Coronavirus Apps Is Tracking Us. Now It's Time to Keep Track of Them. MIT Technology Review, 2020. Available online: https:/ /www.technologyreview.com/2020/05/07/1000961/launchingmittr-covid-tracing-tracker / (accessed on 25 April 2021).

10. Du, L.; Raposo, V.L.; Wang, M. COVID-19 Contact Tracing Apps: A Technologic Tower of Babel and the Gap for International Pandemic Control. JMIR mHealth uHealth 2020, 8, e23194. [CrossRef] [PubMed]

11. COVID-19 National Emergency Response Center, Epidemiology \& Case Management Team, Korea Centers for Disease Control \& Prevention Contact Transmission of COVID-19 in South Korea: Novel Investigation Techniques for Tracing Contacts. Osong Public Health Res. Perspect. 2020, 11, 60-63. [CrossRef]

12. Goniewicz, K.; Khorram-Manesh, A. Maintaining Social Distancing during the COVID-19 Outbreak. Soc. Sci. 2021, 10, 14. [CrossRef]

13. Rowe, F.; Ngwenyama, O.; Richet, J.-L. Contact-tracing apps and alienation in the age of COVID-19. Eur. J. Inf. Syst. 2020, 29, 545-562. [CrossRef]

14. McGrail, K.M. Contact-Tracing Apps: Time to Confront Broader Societal Change. Am. J. Public Health 2021, 111, 369-370. [CrossRef]

15. Bernard, R.; Bowsher, G.; Sullivan, R. COVID-19 and the Rise of Participatory SIGINT: An Examination of the Rise in Government Surveillance through Mobile Applications. Am. J. Public Health 2020, 110, 1780-1785. [CrossRef]

16. Lund University in Collaboration with Uppsala University and Kings's College London. COVID Symptom Study. Available online: https:/ / www.covid19app.lu.se/ (accessed on 25 April 2021).

17. Shuja, J.; Alanazi, E.; Alasmary, W.; Alashaikh, A. COVID-19 open source data sets: A comprehensive survey. Appl. Intell. 2021, 51, 1296-1325. [CrossRef]

18. Michael, K.; Abbas, R. Behind COVID-19 Contact Trace Apps: The Google-Apple Partnership. IEEE Consum. Electron. Mag. 2020, 9, 71-76. [CrossRef]

19. Baumgart, D.C. Digital advantage in the COVID-19 response: Perspective from Canada's largest integrated digitalized healthcare system. NPJ Digit. Med. 2020, 3, 1-4. [CrossRef] [PubMed]

20. Jacob, S.; Lawarée, J. The adoption of contact tracing applications of COVID-19 by European governments. Policy Des. Pract. 2020, 4, 1-15. [CrossRef]

21. Information Commissioner's Office. Guide to the General Data Protection Regulation (GDPR). Information Commissioner's Office. 2018. Available online: https://ico.org.uk/media/for-organisations/guide-to-the-general-data-protection-regulationgdpr-1-0.pdf (accessed on 25 April 2021).

22. Alanzi, T. A Review of Mobile Applications Available in the App and Google Play Stores Used during the COVID-19 Outbreak. J. Multidiscip. Health 2021, 14, 45-57. [CrossRef]

23. Maghdid, H.S.; Ghafoor, K.Z. A Smartphone Enabled Approach to Manage COVID-19 Lockdown and Economic Crisis. SN Comput. Sci. 2020, 1, 1-9. [CrossRef]

24. Sowmiya, B.; Abhijith, V.; Sudersan, S.; Sundar, R.S.J.; Thangavel, M.; Varalakshmi, P. A Survey on Security and Privacy Issues in Contact Tracing Application of Covid-19. SN Comput. Sci. 2021, 2, 1-11. [CrossRef] [PubMed]

25. Davalbhakta, S.; Advani, S.; Kumar, S.; Agarwal, V.; Bhoyar, S.; Fedirko, E.; Prasanna Misra, D.; Goel, A.; Gupta, L.; Agarwal, V. A Systematic Review of Smartphone Applications Available for Corona Virus Disease 2019 (COVID19) and the Assessment of their Quality Using the Mobile Application Rating Scale (MARS). J. Med. Syst. 2020, 44, 1-15. [CrossRef] [PubMed] 
26. Li, Z.; Chen, Q.; Feng, L.; Rodewald, L.; Xia, Y.; Yu, H.; Zhang, R.; An, Z.; Yin, W.; China CDC COVID-19 Emergency Response Strategy Team; et al. Active case finding with case management: The key to tackling the COVID-19 pandemic. Lancet 2020, 396, 63-70. [CrossRef]

27. Sultan, M.; Sørensen, J.L.; Carlström, E.; Mortelmans, L.; Khorram-Manesh, A. Emergency Healthcare Providers' Perceptions of Preparedness and Willingness to Work during Disasters and Public Health Emergencies. Healthcare 2020, 8, 442. [CrossRef]

28. Guillon, M.; Kergall, P. Attitudes and opinions on quarantine and support for a contact-tracing application in France during the COVID-19 outbreak. Public Health 2020, 188, 21-31. [CrossRef]

29. Gerli, P.; Arakpogun, E.O.; Elsahn, Z.; Olan, F.; Prime, K.S. Beyond Contact-Tracing: The Public Value of eHealth Application in a Pandemic. Gov. Inf. Q. 2021, 101581. [CrossRef]

30. Ben Jaffel, H.; Hoffmann, A.; Kearns, O.; Larsson, S. Collective Discussion: Toward Critical Approaches to Intelligence as a Social Phenomenon. Int. Political Sociol. 2020, 14, 323-344. [CrossRef]

31. Abdullahi, L.; Onyango, J.; Mukiira, C.; Wamicwe, J.; Githiomi, R.; Kariuki, D.; Mugambi, C.; Wanjohi, P.; Githuka, G.; Nzioka, C.; et al. Community interventions in Low-And Middle-Income Countries to inform COVID-19 control implementation decisions in Kenya: A rapid systematic review. PLoS ONE 2020, 15, e0242403. [CrossRef] [PubMed]

32. Niccolai, L.; Shelby, T.; Weeks, B.; Schenck, C.; Goodwin, J.; Hennein, R.; Rossini, M.; Vazquez, J.; van Rhijn, D.; Meek, J.; et al. Community Trace: Rapid Establishment of a Volunteer Contact Tracing Program for COVID-19. Am. J. Public Health 2021, 111, 54-57. [CrossRef] [PubMed]

33. Abuhammad, S.; Khabour, O.F.; Alzoubi, K.H. COVID-19 Contact-Tracing Technology: Acceptability and Ethical Issues of Use. Patient Prefer. Adherence 2020, 14, 1639-1647. [CrossRef]

34. Shivaji, B.; Anindhya, S. COVID-19: Implications on the Data Protection Framework in India. Mondaq Business Briefing, 6 May 2020. Available online: https:/ /www.mondaq.com/india/data-protection/928998/covid-19-implications-on-the-data-protectionframework-in-india(accessed on 26 April 2021).

35. Riemer, K.; Ciriello, R.; Peter, S.; Schlagwein, D. Digital contact-tracing adoption in the COVID-19 pandemic: IT gov-ernance for collective action at the societal level. Eur. J. Inf. Syst. 2020, 29, 731-745. [CrossRef]

36. Basu, S. Effective Contact Tracing for COVID-19 Using Mobile Phones: An Ethical Analysis of the Mandatory Use of the Aarogya Setu Application in India. Camb. Q. Health Ethics 2021, 30, 262-271. [CrossRef]

37. Collins, E.C. Evolving Considerations for Multinational Employers: COVID-19 Contact Tracing Applications. Natl. Law Rev. 2021, XI, 116.

38. Ling, G.H.T.; Suhud, N.A.B.M.; Leng, P.C.; Yeo, L.B.; Cheng, C.T.; Ahmad, M.H.H.; Matusin, A.M.R.A. Factors Influencing Asia-Pacific Countries' Success Level in Curbing COVID-19: A Review Using a Social-Ecological System (SES) Framework. Int. J. Environ. Res. Public Health 2021, 18, 1704. [CrossRef]

39. Maati, A.; Švedkauskas, Ž. Framing the Pandemic and the Rise of the Digital Surveilance State. Czech J. Int. Relat. 2020, 55, 48-71. [CrossRef]

40. Rothstein, M.A. From SARS to Ebola: Legal and Ethical Considerations for Modern Quarantine. Indiana Health Law Rev. 2015, 12, 227-280. [CrossRef]

41. Nguyen, T.V.; Tran, Q.D.; Phan, L.T.; Vu, L.N.; Truong, D.T.T.; Truong, H.C.; Le, T.N.; Vien, L.D.K.; Nguyen, T.V.; Luong, Q.C.; et al. In the interest of public safety: Rapid response to the COVID-19 epidemic in Vietnam. BMJ Glob. Health 2021, 6, e004100. [CrossRef] [PubMed]

42. Hassandoust, F.; Akhlaghpour, S.; Johnston, A.C. Individuals' privacy concerns and adoption of contact tracing mobile applications in a pandemic: A situational privacy calculus perspective. J. Am. Med. Inform. Assoc. 2021, 28, 463-471. [CrossRef] [PubMed]

43. Bradshaw, E.L.; Ryan, R.M.; Noetel, M.; Saeri, A.K.; Slattery, P.; Grundy, E.; Calvo, R. Information Safety Assurances Increase Intentions to Use COVID-19 Contact Tracing Applications, Regardless of Autonomy-Supportive or Controlling Message Framing. Front. Psychol. 2021, 11, 591638. [CrossRef] [PubMed]

44. United Nation Disaster Risk Reduction (UNDRR). Sendai Framework for Disaster Risk Reduction 2015-2030. Available online: https:/ / www.undrr.org/implementing-sendai-framework/what-sendai-framework (accessed on 26 April 2021).

45. Page, M.J.; McKenzie, J.E.; Bossuyt, P.M.; Boutron, I.; Hoffmann, T.C.; Mulrow, C.D.; Shamseer, L.; Tetzlaff, J.M.; Akl, E.A.; Brennan, S.E.; et al. The PRISMA 2020 statement: An updated guideline for reporting systematic reviews. BMJ 2021, 372, n71. [CrossRef]

46. Health Evidence Quality Assessment Tool. Available online: https://www.healthevidence.org/documents/our-appraisal-tools/ QA_Tool\&Dictionary_10Nov16.pdf (accessed on 26 April 2021).

47. Stemler, S. An Overview of content analysis. Practical Assessment. Res. Eval. 2000, 7, 17. [CrossRef]

48. Center for Disease Control (CDC) Contact Tracing Resources. Available online: https://www.cdc.gov/coronavirus/2019-ncov/ php/open-america/contact-tracing-resources.html (accessed on 25 April 2021).

49. Legendre, F.; Humbert, M.; Mermoud, A.; Lenders, V. Contact Tracing: An overview of technologies and cyber risks. arXiv 2007, arXiv:2007.02806.

50. Bachtiger, P.; Adamson, A.; Quint, J.K.; Peters, N.S. Belief of previous COVID-19 infection and unclear government policy are associated with reduced willingness to participate in App-based contact tracing: A UK-wide observational study of 13,000 people. medRxiv 2020. [CrossRef] 
51. Ekong, I.; Chukwu, E.; Chukwu, M. COVID-19 Mobile Positioning Data Contact Tracing and Patient Privacy Regulations: Exploratory Search of Global Response Strategies and the Use of Digital Tools in Nigeria. JMIR mHealth uHealth 2020, 8, e19139. [CrossRef]

52. Goniewicz, K.; Khorram-Manesh, A.; Hertelendy, A.J.; Goniewicz, M.; Naylor, K.; Burkle, J.F.M. Current Response and Management Decisions of the European Union to the COVID-19 Outbreak: A Review. Sustainability 2020, 12, 3838. [CrossRef]

53. Williams, S.N.; Armitage, C.J.; Tampe, T.; Dienes, K. Public attitudes towards COVID-19 contact tracing apps: A UK-based focus group study. Health Expect. 2021, 24, 377-385. [CrossRef]

54. Chen, A.T.; Ge, S.; Cho, S.; Teng, A.K.; Chu, F.; Demiris, G.; Zaslavsky, O. Reactions to COVID-19, information and technology use, and social connectedness among older adults with pre-frailty and frailty. Geriatr. Nurs. 2021, 42, 188-195. [CrossRef] [PubMed]

55. Dong, W.; Tao, J.; Xia, X.; Ye, L.; Xu, H.; Jiang, P.; Liu, Y. Public Emotions and Rumors Spread During the COVID-19 Epidemic in China: Web-Based Correlation Study. J. Med. Internet Res. 2020, 22, e21933. [CrossRef]

56. Sfendla, A.; Hadrya, F. Factors Associated with Psychological Distress and Physical Activity during the COVID-19 Pandemic. Health Secur. 2020, 18, 444-453. [CrossRef] [PubMed]

57. Smith, L.; Amlô t, R.; Lambert, H.; Oliver, I.; Robin, C.; Yardley, L.; Rubin, G. Factors associated with adherence to self-isolation and lockdown measures in the UK: A cross-sectional survey. Public Health 2020, 187, 41-52. [CrossRef]

58. Shah, A.; Aacharya, R.P. Combating COVID-19 Pandemic in Nepal: Ethical Challenges in an Outbreak. J. Nepal Med. Assoc. 2020, 58, 276-279. [CrossRef] [PubMed]

59. O'Callaghan, M.E.; Buckley, J.; Fitzgerald, B.; Johnson, K.; Laffey, J.; McNicholas, B.; Nuseibeh, B.; O’Keeffe, D.; O’Keeffe, I.; Razzaq, A.; et al. A national survey of attitudes to COVID-19 digital contact tracing in the Republic of Ireland. Ir. J. Med. Sci. 2020, 1-25. [CrossRef]

60. Charania, N.A.; Tsuji, L.J. The 2009 H1N1 pandemic response in remote First Nation communities of Subarctic Ontario: Barriers and improvements from a health care services perspective. Int. J. Circumpolar Health 2011, 70, 564-575. [CrossRef]

61. Cantey, P.T.; Chuk, M.G.; Kohl, K.S.; Herrmann, J.; Weiss, P.; Graffunder, C.M.; Averhoff, F.; Kahn, E.B.; Painter, J. Public health emergency preparedness: Lessons learned about monitoring of interventions from the National Association of County and City Health Official's survey of nonpharmaceutical interventions for pandemic H1N1. J. Public Health Manag. Pract. 2013, 19, 70-76. [CrossRef] [PubMed]

62. A Charania, N.; Tsuji, L.J.S. A community-based participatory approach and engagement process creates culturally appropriate and community informed pandemic plans after the 2009 H1N1 influenza pandemic: Remote and isolated First Nations communities of sub-arctic Ontario, Canada. BMC Public Health 2012, 12, 268. [CrossRef]

63. Li, Z.-J.; Tu, W.-X.; Wang, X.-C.; Shi, G.-Q.; Yin, Z.-D.; Su, H.-J.; Shen, T.; Zhang, D.-P.; Li, J.-D.; Lv, S.; et al. A practical community-based response strategy to interrupt Ebola transmission in sierra Leone, 2014-2015. Infect. Dis. Poverty 2016, 5, 1-10. [CrossRef] [PubMed]

64. Ye, J. Pediatric Mental and Behavioral Health in the Period of Quarantine and Social Distancing with COVID-19. JMIR Pediatr. Parent. 2020, 3, e19867. [CrossRef]

65. Kim, J.; Park, H.-A. Development of a Health Information Technology Acceptance Model Using Consumers' Health Behavior Intention. J. Med. Internet Res. 2012, 14, e133. [CrossRef] [PubMed]

66. Neupane, H.C.; Shrestha, N.; Adhikari, S.; Gauli, B. COVID 19 and Nepal: Identification of Critical Public Health Measures. J. Nepal Med. Assoc. 2020, 58, 355-359. [CrossRef] [PubMed]

67. Rothstein, M.A. The Coronavirus Pandemic: Public Health and American Values. J. Law Med. Ethics 2020, 48, 354-359. [CrossRef]

68. Smith, C.L.; Hughes, S.M.; Karwowski, M.P.; Chevalier, M.S.; Hall, E.; Joyner, S.N.; Ritch, J.; Smith, J.C.; Weil, L.M.; Chung, W.M.; et al. Addressing Needs of Contacts of Ebola Patients During an Investigation of an Ebola Cluster in the United States-Dallas, Texas, 2014. MMWR Morb. Mortal. Wkly. Rep. 2015, 64, 121-123. [PubMed]

69. Joo, J.; Shin, M.M. Resolving the tension between full utilization of contact tracing app services and user stress as an effort to control the COVID-19 pandemic. Serv. Bus. 2020, 14, 461-478. [CrossRef]

70. Torous, J.; Myrick, K.J.; Rauseo-Ricupero, N.; Firth, J. Digital Mental Health and COVID-19: Using Technology Today to Accelerate the Curve on Access and Quality Tomorrow. JMIR Ment. Health 2020, 7, e18848. [CrossRef]

71. DeWalt, D.A.; Berkman, N.D.; Sheridan, S.L.; Lohr, K.N.; Pignone, M.P. Literacy and health outcomes. J. Gen. Intern. Med. 2004, 19, 1228-1239. [CrossRef]

72. AHRQ (Agency for Healthcare Research and Quality). National Healthcare Disparities Report; AHRQ: Rockville, MD, USA, 2007.

73. Paasche-Orlow, M.K.; Parker, R.M.; Gazmararian, J.A.; Nielsen-Bohlman, L.T.; Rudd, R.R. The prevalence of limited health literacy. J. Gen. Intern. Med. 2005, 20, 175-184. [CrossRef]

74. Rajah, R.; Hassali, M.; Murugiah, M. A systematic review of the prevalence of limited health literacy in Southeast Asian countries. Public Health 2019, 167, 8-15. [CrossRef]

75. Baccolini, V.; Rosso, A.; Di Paolo, C.; Isonne, C.; Salerno, C.; Migliara, G.; Prencipe, G.P.; Massimi, A.; Marzuillo, C.; De Vito, C.; et al. What is the Prevalence of Low Health Literacy in European Union Member States? A Systematic Review and Meta-analysis. J. Gen. Intern. Med. 2021, 36, 753-761. [CrossRef] [PubMed]

76. Tambo, E.; Djuikoue, I.C.; Tazemda, G.K.; Fotsing, M.F.; Zhou, X.N. Early stage risk communication and community engagement (RCCE) strategies and measures against the coronavirus disearse 2019 (COVID-19) pandemic crisis. Glob. Health J. 2021, 5, 44-50. [CrossRef] [PubMed] 
77. Simon, S. Subtle Connections: Pandemic and the Authoritarian Impulse. Survival 2020, 62, 103-111. [CrossRef]

78. Nelson, C.; Lurie, N.; Wasserman, J.; Zakowski, S. Conceptualizing and Defining Public Health Emergency Preparedness. Am. J. Public Health 2007, 97, S9-S11. [CrossRef] 